\title{
A CASE FOR INCREASED FORAGING SUCCESS UNDER HIGH CONSPECIFIC DENSITIES IN THE NEW ZEALAND MUDSNAIL, POTAMOPYRGUS ANTIPODARUM
}

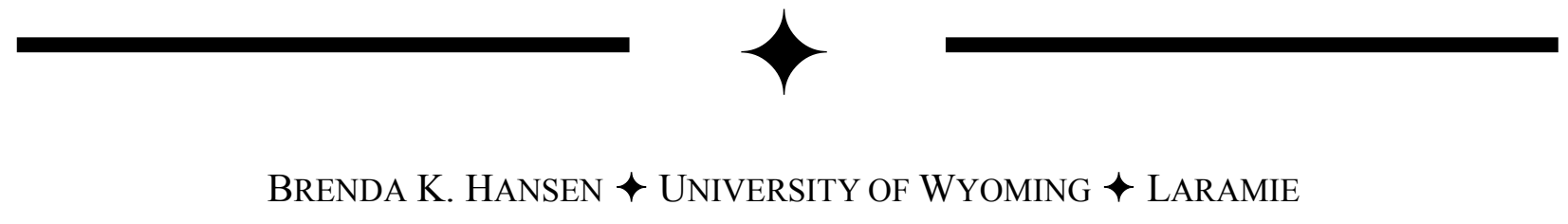

\section{$\uparrow \quad$ AbSTRACT}

An animals' fitness can be positively or negatively affected by the density of conspecifics. While density dependent increases in fitness, or Allee effects, have been a key focus of the management of declining populations of native organisms, they may also be exploited for the purpose of invasive species management. Although most Allee studies focus primarily on mate location, a threshold density of conspecifics may also be required for effective foraging. Potamopyrgus antipodarum is a successful invader that can reach very high densities. Previous studies have demonstrated that $P$. antipodarum benefits from certain high densities through increased reproduction and activity. To determine whether conspecific density positively affects the foraging ability of $P$. antipodarum, I conducted laboratory experiments with three increasing levels of density (one, five and 15 individuals, control targets were alone). Because the presence of interactors may also affect the type of food individuals choose, I also included two food options differing in the amount of phosphorus, which is an important nutrient known to be limited in one invaded stream. Although food choice was unaffected by conspecific density, P. antipodarum were more likely to feed and fed longer in the higher density treatments; target snails in the treatment containing 15 conspecifics fed three times as long as targets in the treatment with five conspecifics. These results provide further insight into the ecology of $P$. antipodarum, and their success as invaders. Further work is needed to determine how this species uses high density to locate food resources.

\section{$\uparrow \quad$ INTRODUCTION}

Invasive species, non-indigenous species that cause ecological or economic harm, are one of the leading causes of global biodiversity loss (Sala et al. 2000). As a result, there is increasing interest in identifying the mechanisms that lead to successful invasion (Sakai et al. 2001, Taylor and Hastings 2005). Successful invasions require minimum founding populations for the establishment and growth of viable populations, and the spread of these populations through the invaded region (Parker et al. 1999). Invaders that are able to reach high population densities will be more likely to dominate, negatively affecting native ecosystems (Hall et al. 2006, McKenzie et al. 2013). Although high invader densities can result in both intra- and interspecific competition for space and nutrients (Schloesser 1996, Strayer 1999), high densities may provide fitness benefits for some invaders through increased mating opportunities, predator avoidance and improved foraging strategies (Kramer et al. 2009). These types of density-dependent increases in fitness (Allee 1931) should be particularly strong during early stages of invasion, when the probability of locating mates affects the likelihood of extinction in the invaded range (Taylor and Hastings 2005, Lockwood et al. and references therein 2007, Tobin et al. 2011). Although they have received much less attention, Allee effects that are not directly related to mate location (hereafter non-reproductive Allee effects), such as predator avoidance and food location, may profoundly affect the success of an invader. Because asexual invaders do not require mates, they are ideal for studying nonreproductive Allee effects. 
Potamopyrgus antipodarum (Hydrobiidae, Mollusca; Gray 1843) is a freshwater snail native to New Zealand. While both sexual and asexual populations are found in the native range (Winterbourn 1970, Lively 1987), only the parthenogenetic females are known invaders (Jacobsen and Forbes 1997, Alonso and Castro-Diez 2008). Potamopyrgus antipodarum have successfully invaded multiple habitat types, world-wide, likely resulting from their ability to tolerate a wide range of temperatures and salinities (Winterbourn 1969, 1970), and high relative growth rates (Hall et al. 2006, Tibbets et al. 2010). The high growth rates of $P$. antipodarum suggest that these snails should have high nutrient demands (Elser et al. 2000). However, the resources in which they live are often nutrient limited (Cross et al. 2005, Tibbets et al. 2010), suggesting that $P$. antipodarum populations should be sensitive to nutrient availability. Despite often living in environments with low nutrient availability, invasive $P$. antipodarum can occur in very high population densities $\left(500,000 / \mathrm{m}^{2}\right.$ in one stream, Hall et al. 2006), making them ideal for studying invasion biology (Alonso and Castro-Diez 2008, Liess and Lang 2011) and potential non-reproductive Allee effects. My experiment investigated whether $P$. antipodarum benefits from high conspecific densities through more effective foraging.

Potamopyrgus antipodarum may increase individual fitness in the presence of multiple conspecifics. Two laboratory experiments showed that individual $P$. antipodarum substantially increased reproductive output in the presence of high conspecific densities (Brenneis et al. 2010 and Neiman et al. 2013). Additionally, P. antipodarum increased overall activity (Liess and Lange 2011) and were more likely to feed (Hansen 2013) in the presence of many conspecifics. I conducted laboratory behavioral trials with field-caught $P$. antipodarum to determine whether feeding activity or choice of food is positively affected by high conspecific density.

\section{$\uparrow \quad$ METHODS}

\section{Study Animals}

In June 2012, I collected adult $P$. antipodarum (3.5 - $5 \mathrm{~mm}$ length) from lower Polecat Creek near Flagg Ranch (Rockefeller National Parkway, WY) with aquatic nets. All snails in the GYE are members of the US1 clonal lineage (Dybdahl and Drown 2011). Snails were housed in aquaria in the UW Zoology and Physiology Animal Facility, at $23^{\circ} \mathrm{C}$ on a 12 hour light cycle, and allowed to acclimate to the laboratory environment for one week prior to the start of experiments. During the acclimation period, I fed snails an ad libitum diet of organic leaf lettuce, goldfish flakes and algae pellets.

\section{Experimental Diet}

For the experimental diet, I cultured the green algae, Scenedesmus acutus, with a nutrient medium containing identical $\mathrm{N}$ and either low $(\mathrm{C}: \mathrm{P} \sim 1,119)$ or high (C:P 203) amounts of $\mathrm{P}$ (Dobberfuhl and Elser 1999). I manipulated phosphorus level because $P$. antipodarum is known to be limited by the availability of phosphorus (Tibbets et al. 2010). After cultures grew for one week, I concentrated the algae in a centrifuge. I pipetted $0.25 \mathrm{~mL}$ of concentrated algae into aluminum weigh boats $(3.5 \mathrm{~mm}$ diameter) and placed them in a $60^{\circ} \mathrm{C}$ drying oven for 24 hours. To ensure that algal cells would adhere to the inside of the weigh boats, I scuffed the inner surface of each using a Dremel (120 grit bits) prior to adding food.

\section{Experimental Design}

I asked two related questions: 1) Is the probability of feeding and time spent feeding (foraging activity) influenced by the number of conspecifics and 2 ) is food choice affected by increasing density of conspecifics. To address these questions, I placed two food boats, one containing high $\mathrm{P}$ and one containing low $\mathrm{P}$ algae, in the center of each $300 \mathrm{~mL}(\sim 10 \mathrm{~cm}$ diameter) experimental chamber with all snails (targets and conspecifics) equally spaced from the two food options. Each experimental treatment included 25 replicates. I fasted target snails for three days to increase motivation for feeding. Each replicate ran for five hours and was recorded using a high definition video camera. I analyzed video data for the total time each target spent on each food type.

To address question 1, whether $P$. antipodarum increased feeding activity in the presence of increased conspecific densities, I measured the amount of time a single target snail $(>3.5 \mathrm{~mm})$ fed with zero (control), one, five or 15 similarly-sized (3$5 \mathrm{~mm}$ ) conspecifics. Because chamber size and water volume was identical among treatments, I defined density as the number of animals per chamber. I painted the target snails with nail polish so that I could observe individual behavior. I compared the probability of feeding among density treatments using a Fisher's Exact Test. To assess whether the presence of any conspecifics affected foraging activity, I first compared the controls (no conspecifics) to the combined density treatments using a t-test. Then, to determine whether varying densities of conspecifics 
affected foraging activity, I omitted controls and used a one-way ANOVA to determine whether density of conspecifics affected foraging activity. I used a square root transformation of the total time feeding (minutes) to achieve homoscedasticity. For both probability of feeding and foraging activity, I omitted replicates where no feeding occurred and I combined data from both food types. I defined feeding events as any time that a target snail was inside of a food boat. Finally, I conducted another Fisher's Exact Test to learn whether different conspecific densities affected the probability of choosing high quality food. All statistics were conducted using the $\mathrm{R}$ statistical package ( $\mathrm{R}$ Development Core Team, 2012).

\section{$\uparrow \quad$ Results}

The number of target snails that fed on either food type differed among treatments (Fisher's Exact Test, $p=0.006$ ) such that the number doubled between one and five conspecifics and tripled from five to 15 conspecifics. However, the total amount of time $P$. antipodarum spent feeding did not differ between controls and all treatments of conspecific densities combined $\left(\mathrm{t}_{20}=0.2104, \mathrm{p}=0.835\right)$. Among density treatments, the amount of time that target snails fed differed $\left(F_{2,15}=2.91, p=0.085\right.$; Figure 1$)$ such that snails fed ten times longer with five conspecifics relative to one conspecific, and twice as long with 15 conspecifics relative to five.

However, I found no effect of varying conspecific density on the probability of choosing high $\mathrm{P}$ or low P food (Fisher's exact test, $\mathrm{p}=0.115$ ).

\section{$\uparrow$ DISCUSSION}

Identifying the traits that characterize successful invaders is critical to predicting likely invaders, and to minimizing the impacts of established invasive populations. Potamopyrgus antipodarum is a successful aquatic invader, and has been shown to negatively affect native grazers in field (Riley et al. 2008) and laboratory experiments (Thon and Krist in prep.). High relative growth rates and percent body phosphorus (Tibbets et al. 2010) suggest that $P$. antipodarum should have a high $P$ demand (Elser et al. 2003). However, because $P$ is often limiting in benthic resources (Cross et al. 2005), it is not clear how $P$. antipodarum is able to maintain high population densities in invaded habitats. Although my results suggest that increased conspecifics do not improve the ability of snails to choose food that is high in P, they do suggest that greater numbers of conspecifics may improve the foraging activity of this snail. While the threshold for a positive effect on foraging may occur with fewer than 15 conspecifics (e.g. ten), under my experimental conditions more target $P$. antipodarum fed and spent the most amount of time feeding when 15 conspecifics were present. It is possible that even higher densities of conspecifics will have a stronger positive effect of $P$. antipodarum foraging behavior.

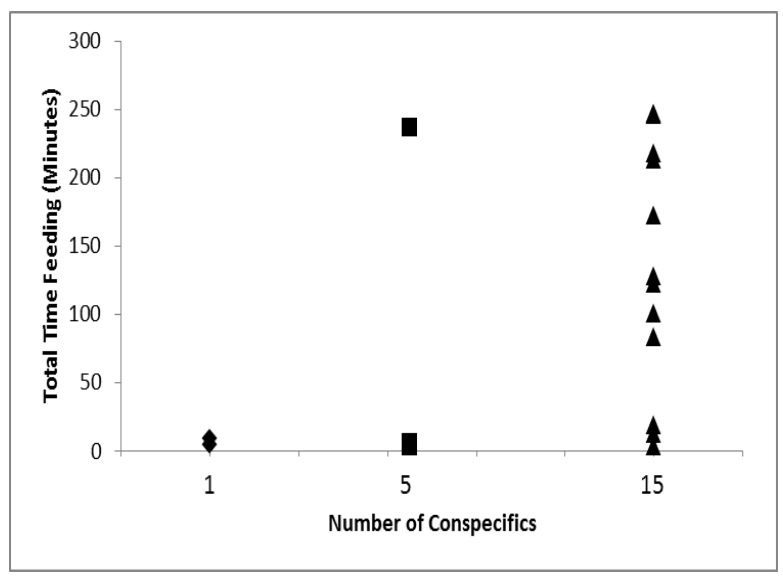

Figure 1. The invasive snail, Potamopyrgus antipodarum, altered foraging activity (measured as the amount of time feeding by a target snail) in the presence of three levels of conspecific density $\left(f_{2,15}=2.91, p=0.085\right)$. When the high outlier from the treatment with five conspecifics, and the three smallest outliers from the treatment with 15 conspecifics were removed, there was no apparent difference between treatments containing one and five conspecifics, but target snails from both spent significantly less time feeding than targets with 15 conspecifics (Tukey-Kramer: $p=0.0002$ and $\mathrm{p}<0.0001$ respectively).

My results are similar to other work that suggests $P$. antipodarum benefits from high densities of conspecifics through increased reproductive output (Brenneis et al. 2010, Neiman et al. 2013) and activity (Liess and Lange 2011). In addition, growth of $P$. antipodarum was much less affected than a native snail, Fossaria, by very high densities of conspecifics in a laboratory experiment (Thon and Krist in prep.). Although I did not examine very high densities, my results demonstrate that $P$. antipodarum is more likely to feed with at least 15 conspecifics present. Increased probability of feeding by $P$. antipodarum may be explained by chemical cues produced by feeding individuals, which attract conspecifics to food patches. This response has been shown in many social animals (Aguilar and Sommeijer 2001, Saleh et al. 2007), and in asocial rattlesnakes (Clark 2007). It is also possible that, similar to some hermit crabs (Laidre 2010), P. antipodarum locates food visually, based on the presence of conspecifics on food resources. 
The lack of an effect of increased conspecifics on food choice may suggest that $P$. antipodarum is unable to distinguish differences in food quality. Perhaps $P$. antipodarum lack the sensory ability to locate resources based on nutrient quality. Furthermore, the increase in the probability of feeding at higher densities could mean that $P$. antipodarum was unable to successfully locate the algae by olfaction. If this snail cannot detect algae, an increase in density simply increased the probability of an individual randomly finding the food, with additional individuals following the chemical or visual cues of the successful snail. Although one study did identify preference for certain food types by $P$. antipodarum (Haynes and Taylor 1984), their experimental chambers contained 250 animals and their results did not distinguish between individual choice and conspecific facilitation. It is also possible that $P$. antipodarum can distinguish between different types of resources, such as plant and animal material (Haynes and Taylor 1984), but not differences in quality of one specific species, as in my experiment.

Because I showed that some densities positively affect the foraging behavior of $P$. antipodarum, my results highlight the importance of including Allee effects in future invasion studies. Because invasive species require a minimum population size for establishment and spread, identifying and exploiting density-dependent traits of invasive species may facilitate management of established populations. Identifying the minimum population size necessary for the establishment of $P$. antipodarum would advance our understanding of how Allee effects contribute to the invasion success of this species.

\section{ACKNOWLEDGEMENTS}

This project would not have been possible without funding from the Louis C. "Red" Rocket, Verne Bressler, and L. Floyd Clarke scholarships. I would also like to thank my co-chairs, Amy Krist and Carlos Martinez del Rio, and my committee members, Tim Collier and Teresa Tibbets for input and support through the course of my Master's. Additionally, I am grateful for the logistic support from Joe Bobbitt and Steve Devries at Red Buttes, Robert Carroll, as well as the AMK Research Facility and Hank and Maryann Harlow. Finally, I thank Miranda Bryant, Heidi Meador, Jake Peters, Matthew Hansen, Katheryn Napier, Jonathan Rader, a family of otters and thousands of snails for their assistance with dozens of collection hours in the field.

\section{Literature Cited}

Aguilar I, Sommeijer M. 2001. The deposition of anal excretions by Melipona favosa foragers (Apidae: Meliponinae): behavioural observations concerning the location of food sources. Apidologie. 32:37-48.

Allee WC. 1931. Animal aggregations, a study in general sociology. University of Chicago Press, Chicago.

Alonso A, Castro-Díez P. 2008. What explains the invading success of the aquatic mud snail Potamopyrgus antipodarum (Hydrobiidae, Mollusca)? Hydrobiologia, 614:107-116.

Brenneis VEF, Sih A, de Rivera CE. 2010. Coexistence in the intertidal: interactions between the non-indigenous New Zealand mud snail Potamopyrgus antipodarum and the native estuarine isopod Gnorimosphaeroma insulare. Oikos. 119:1755-1764.

Clark RW. 2007. Public information for solitary foragers: timber rattlesnakes use conspecific chemical cues to select ambush sites. Behavioral Ecology. 18(2):487-490

Cross WF, Benstead JP, Frost PC, Thomas SA. 2005. Ecological stoichiometry in freshwater benthic systems: recent progress and perspectives. Freshwater Biology. 50:18951912.

Dobberfuhl DR, JJ Elser. 1999. Use of dried algae as a food source for zooplankton growth and nutrient release experiments. Journal of Plankton Research. 21:957-970.

Dybdahl MF, Drown DM. 2011. The absence of genotypic diversity in a successful parthenogenetic invader. Biological Invasions. 13:1663- 1672.

Elser JJ, Fagan WF, Denno RF, Dobberfuhl DR, Folarin A, Huberty A, Interlandi S, Kilham SS, McCauley E, Shulz EL, et al 2000. Nutritional constraints in terrestrial and freshwater food webs. Nature. 408:578-580.

Hall RO Jr., Dybdahl MF, Vanderloop MC. 2006. Extremely high secondary production of 
introduced snails in rivers. Ecological Applications. 16 (3):1121-1131.

Hansen BK. 2013. M.S. Thesis Behavioral Compensation in a low phosphorus environment and the benefits of high density in an invasive snail. University of Wyoming.

Haynes A, Taylor BJR. 1984. Food finding and food preference in Potamopyrgus jenkinsi (EA Smith) (Gastropoda: Prosobranchia). Arch. Hydrobioloical. 100(4):479-491.

Jacobsen R, Forbes VE. 1997. Clonal variation in lifehistory traits and feeding rates in the gastropod, Potamopyrgus antipodarum: performance across a salinity gradient. Functional Ecology. 11:260-267.

Kramer AM, Dennis B, Liebhold AM, Drake JM. 2009. The evidence for Allee effects. Population Ecology, 51:341-354.

Laidre ME. 2010. How rugged individualists enable one another to find food and shelter: field experiments with tropical hermit crabs. Proceedings of the Royal Society B. 277:1361-1369.

Liess A, Lange K. 2011. The snail Potamopyrgus antipodarum grows faster and is more active in the shade, independent of food quality. Oecologia. 167:85-96.

Lively CM. 1987. Evidence from a New Zealand snail for the maintenance of sex by parasitism. Nature. 328:519-521.

Lockwood JL, Hoopes MF, Marchetti MP. 2007. Invasion Ecology. Blackwell Publishing, Malden, MA, USA

McKenzie VJ, Hall WE, Guralnick RP. 2013. New Zealand mudsnails (Potamopyrgus antipodarum) in Boulder Creek, Colorado: environmental factors associated with fecundity of a parthenogenic invader. Canadian Journal of Zoology. 91:30-36.

Neiman M, Warren D, Rasnuissen B, Zhang S. 2013. Complex consequences of increased density for reproductive output in an invasive freshwater snail. Evolutionary Ecology 1-11.

Parker IM, Simberloff D, Lonsdale WM, Goodell K, Wonham M, Kareiva PM, Williamson MH,
Von Holle B, Moyle PB, Byers JB, Goldwasser L. 1999. Impact: toward a framework for understanding the ecological effects of invaders. Biological Invasions 1:319.

R Development Core Team, 2012. R; A language and environment for statistical computing. $\mathrm{R}$ Foundation for Statistical Computing, Vienna, Austria. ISBN 3-900051 -07-0, URL http://www.R-project.org.

Riley LA, MF Dybdahl, RO Hall. 2008. Invasive species impact: asymmetric interactions between invasive and endemic freshwater snails Journal of North American Benthological Society. 27:509-520.

Sakai AK, FW Allendorf, JS Holt, DM Lodge, J Molofsky, KA With, S Baughman, RJ Cabin, JE Cohen, NC Ellstrand, DE McCauley, P O’Neil, IM Parker, JN Thompson, and SG Weller. 2001. The population biology of invasive species. Annual Review. Ecological Systems. 32:305-332.

Sala OE, Chapin III S, Armesto JJ, Berlow E, Bloomfield J, Dirzo R, Huber-Sanwald E, Huenneke LF, Jackson RB, Kinzig A, Leemans R, Lodge DM, Mooney HA, Oesterheld M, Poff NL, Sykes MT, Walker BH, Walker M, Wall DH. 2000. Global biodiversity scenarios for the year 2100 . Science. 287:1770-74.

Saleh N, Scott AG, Bryning GP, Chittka L. 2007. Distinguishing signals and cues: bumblebees use general footprints to generate adaptive behaviour at flowers and nest. ArthropodPlant Interactions. 1:119-127.

Schloesser DW, Nalepa TF, Mackie GL. 1996. Zebra mussel infestation of unionid bivalves (Unionidae) in North America. American Zoologist. 36:300-310.

Strayer DL. 1999. Effects of alien species on freshwater mollusks in North America. Journal of the North American Benthological Society. 18:74-98

Taylor CM, Hastings A. 2005. Allee effects in biological invasions. Ecology Letters. 8:895908.

Tibbets TM, Krist AC, Hall Jr RO, Riley LA. 2010. Phosphorus-mediated changes in life history 
traits of the invasive New Zealand mudsnail (Potamopyrgus antipodarum). Oecologia. 163:549-559.

Tobin PC, Berec L, Liebhold AM. 2011. Exploiting Allee effects for managing biological invasions. Ecology Letters. 14:615-624.
Winterbourn MJ. 1969. Water temperature as a factor limiting the distribution of Potamopyrgus antipodarum (Gastropoda-Prosobranchia) in the New Zealand thermal region. New Zealand Journal of Marine and Freshwater. 3:453-458.

Winterbourn M. 1970. The New Zealand species of Potamopyrgus (Gastropoda: Hydrobiidae). Malacologia 10(2):283-32. 